\title{
ANALISIS PENGARUH MOTIVASI TERHADAP MINAT MAHASISWA AKUNTANSI UNTUK MENGIKUTI PENDIDIKAN PROFESI AKUNTANSI (PPAk) STUDI PADA PERGURUAN TINGGI NEGERI DI MEDAN
}

\author{
Desi Ika, Yani Suryani \\ Fakultas Ekonomi dan Bisnis, Universitas Harapan Medan, Program Studi Akuntansi \\ Email : desiika082@gmail.com
}

\begin{abstract}
The purpose of this study/research is to analyze the relationship between motivation and interest in accounting students taking the Accounting Profession Education (PPAk) in Medan. Students majoring in accounting at state universities in the city of Medan, North Sumatra, are the population in this study. To test the hypothesis, it was tested using multiple linear regression analysis. From the test results, it is known that prestige motivation, career motivation, economic motivation, and quality motivation simultaneously have a significant influence on the interest of accounting students to take PPAk. However, partially prestige motivation does not have a significant effect on the emergence of interest in accounting students to take PPAk. Career motivation, economic motivation, and quality motivation have a significant influence.
\end{abstract}

Keywords: career motivation, quality, economic, prestige, interest

\begin{abstract}
Abstrak
Tujuan penelaahan/penelitian ini adalah untuk menganalisis hubungan motivasi dengan minat mahasiswa akuntansi mengambil Pendidikan Profesi Akuntansi (PPAk) di Medan. Mahasiswa jurusan akuntansi pada perguruan tinggi negeri yang ada di kota Medan Sumatera Utara sebagai populasi dalam telaah ini. Untuk pengujian hipotesis diuji dengan menggunakan analisis regresi linier berganda. Dari hasil pengujian diketahui, secara simultan motivasi prestise, motivasi karir, motivasi ekonomi, dan motivasi kualitas memiliki pengaruh signifikan terhadap minat mahasiswa akuntansi mengikuti PPAk. Namun secara parsial motivasi prestise tidak memiliki pengaruh signifikan terhadap munculnya minat mahasiswa akuntansi untuk mengikuti PPAk. Motivasi karir, motivasi ekonomi, dan motivasi kualitas secara signifikan memiliki pengaruh.
\end{abstract}

Kata Kunci: motivasi karir, kualitas, ekonomi, prestise, minat

\section{Pendahuluan}

Profesionalisme yang dimiliki oleh para akuntan tidak terlepas dari proses pendidikan tinggi akuntansi yang mereka tempuh. Dalam hal ini sebuah perguruan tinggi akuntansi dituntut untuk mampu menghasilkan para lulusan yang berkualitas agar nantinya mereka mampu bersaing di pasar tenaga kerja. Perguruan tinggi selaku sebuah lembaga yang bertanggung jawab atas masalah kualitas sumber daya manusia telah mengupayakan agar para lulusannya dapat dikatakan berkualitas. Hal ini ditempuh antara lain dengan cara menambah dan mengefektifkan intensitas proses belajar mengajar dengan cakupan materi 


\section{Vol. 2 No. 2 Bulan Oktober 2021 - Maret 2022}

pembelajaran yang cukup baik dan memadai, melengkapi berbagai sarana dan prasarana pendukung belajar serta mendatangkan para tenaga profesional, seperti para praktisi akuntansi yang berkompeten di bidangnya untuk dijadikan sebagai tenaga pendidik.

Namun di sisi lain upaya yang dilakukan oleh perguruan tinggi tersebut tampaknya masih tidak cukup maksimal membendung opini negatif dan ketidak percayaan masyarakat terhadap kualitas dan profesionalisme para akuntan. Hal ini dapat kita cermati dari fenomena banyaknya masyarakat pelaku ekonomi (perusahaan berskala nasional dan internasional) yang memakai bantuan akuntan publik yang berasal dari luar negeri atau mengatas namakan kantor akuntan dari luar negeri.

Fenomena tersebut tentunya sangat memprihatinkan mengingat globalisasi sudah di depan mata. Keadaan ini tidak terlepas dari metode pendidikan yang diterima mahasiswa selama di perguruan tinggi yang lebih mengedepankan aspek teoritis daripada aspek praktis. Penjelasan tersebut sesuai dengan yang dikemukakan Samiaji dalam Widyastuti dkk (2004:321) yaitu "saat ini pendidikan akuntansi menitik beratkan dalam sudut pandang akademis padahal aspek kependidikan profesi penting sehingga memberikan kesan kurang mendapatkan kepedulian".

Berkaitan hal tersebut diperlukan suatu pendidikan yang berbasis karir (profesi) akuntansi yang berkontribusi kepada para mahasiswa dalam menjadikan dirinya seorang akuntan profesional. Selama menempuh pemebelajaran/pendidikan di PPAk para calon akuntan diberikan bekal keterampilan akuntansi yang lebih mendalam dan yang terpenting adalah mereka mengenal dan memahami tentang profesi mereka yang sebenarnya. Dengan diadakannya PPAk memiliki harapan bahwa calon akuntan Indonesia, nantinya dapat bekerja sebagai akuntan profesional dan memiliki kemampuan untuk bersaing secara global sehingga wajar kiranya peminat program ini diprediksikan akan banyak jumlahnya.

Namun, prediksi ini terlihat bertolak belakang dengan keadaan yang sesungguhnya terjadi karena pada kenyataannya, program PPAk sendiri ternyata juga kurang diminati oleh para mahasiswa jurusan akuntansi yang telah lulus mengikuti pendidikan di PT yang dapat dilihat pada rendahnya mahasiswa terdaftar pada program tersebut, khususnya program yang dibuka oleh Fakultas Ekonomi USU. Pengumpulan data dilakukan melalui kantor 
Vol. 2 No. 2 Bulan Oktober 2021 - Maret 2022

pusat informasi program PPAK FE USU menunjukkan angka jumlah peserta program ini tergolong masih minim bila dibandingkan dengan jumlah alumni jurusan akuntansi secara keseluruhan. Mencermati gejala tersebut maka perlu kiranya diteliti bagaimana sebenarnya pandangan para mahasiswa jurusan akuntansi mengenai PPAk dan apa motivasi mereka untuk mengikuti program PPAk.

\section{Tinjauan Pustaka}

\section{Pengertian Motivasi}

Motivasi sebagai "suatu kemauan dan kemampuan melakukan tindakan dalam memperoleh kepuasan seseorang" (Robbins, 2002:55). Pengertian motivasi lainnya adalah keinginan/dorongan/tenaga yang berupa gerakan dalam jiwa maupun jasmani dalam melakukan perbuatan sehingga apa yang dilakukannya memiliki arah atau tujuan (Widyastuti dkk, 2004:326)

Adapun Widyastuti dkk (2004:327) mendefenisikan jenis-jenis motivasi antara lain Motivasi karir, kualitas dan ekonomi. Sedangkan motivasi prestise (gengsi/status) didefenisikan oleh Munandar (2001:86) yaitu "dorongan dan kemauan yang terdapat pada seorang individu untuk dikenali, dipuji dan diakui prestasi kerja dan statusnya serta didengar dan dihargai pandangannya begitu juga dengan keberadaan dirinya yang menyangkut reputasi”".

Beberapa teori dikembangkan untuk menjelaskan faktor-faktor yang memotivasi seseorang termotivasi, serta bagaimanakah seseorang mempertahankan tingkat motivasinya.

Menurut Gibson (2003) teori motivasi terdiri atas dua kelompok yaitu:

\section{Content Theory}

Seringkali disebut kepuasan theory karena mencoba dalam penentuan tingkat kebutuhan individual yang dapat memberikan motivasi seseorang. Dalam teori ini biasanya memberikan ketertarikan pada banyaknya factor yang ada pada individu sehingga dapat menggerakkan, memberi arahan, memberi dukungan maupun mengakhiri tingkah lakunya.

\section{Theory Process.}

Dalam teori ini biasanya diuraikan dan dianalisis tentang suatu perbuatan digerakkan, diberikan arahan, diberikan dukungan, maupun diberhentikan.

Berikut beberapa penjelasan tentang teori motivasi :

a. Teori Tingkat Kebutuhan menurut Maslow yang dicetuskan Abraham Maslow yang membagi tingkatan kebutuhan individu dari yang terendah sampai yang tertinggi, antara lain 


\section{Vol. 2 No. 2 Bulan Oktober 2021 - Maret 2022}

kebutuhan-kebutuhan fisik, keamanan, sosial, kehormatan, dan pengaktualisasian.

b. Aldefer's ERG Theory (yang dicetuskan oleh Clayton Alderfer) dimana teori ini adalah perluasan teori Maslow. Dalam Aldefer's ERG Theory juga membagi keinginan secara berjenjang namun dengan pengelompokan yang lebih sederhana yaitu hanya terdiri dari eksistensi, hubungan sosial, dan mengembangkan diri.

c. Teori Prestasi (McClellands Learnerd Needs Theory). Teori ini dikemukakan oleh Mc Clelland. Teori tersebut menyatakan tentang tiga jenis kebutuhan/keinginan yang dimiliki oleh setiap orang yaitu:

1. Keinginan/Kebutuhan terhadap prestasi

2. Keinginan/Kebutuhan terhadap pengafiliasian

3. Kebutuhan untuk memiliki kekuataan (Need for power)

d. Teori Klasik dari FW Taylor. Teori ini didasarkan atas suatu konsepsi bahwa seseorang melakukan pekerjaan dengan giat, tekun serta mempunyai gairah yang besar dalam bekerja bila kepada yang bersangkutan diberikan imbalan atau jasa sesuai dengan ketentuan yang berlaku. e. Teori Human Relations (Teori Motivasi Hubungan Kemanusiaan). Teori ini memiliki anggapan tentang individu/seseorang yang bersemangat dalam kerja yang tinggi jika dirinya memiliki perasaan dibutuhkan, perasaan dianggap utama/penting, dan perasaan diikut sertakan.

f. Dua Faktor Teori dari Herzberg yang merupakan pengembangan dari dua unsur motivasi untuk pegawai-pegawai yang terdiri dari unsur perasaan puas dan tidak puas yang dimiliki pegawai.

g. Teori Harapan (Expectancy Theory). Seperti telah dijelaskan sebelumnya bahwa pencetus teori ini adalah Victor Vroom. Teori ini disebut juga dengan teori pengutamaan pengharapan.

Dari sekian banyak teori tentang motivasi, maka penelitian ini menggunakan pendekatan teori harapan (expectancy theory) dari Vroom. Ada beberapa alasan digunakannya teori harapan ini yaitu:

1. Teori harapan (ekspektasi) adalah teori motivasi yang sangat erat dengan fenomena di bidang akuntansi di mana dalam penelitian ini teori harapan menekankan pada tujuan apa yang diharapkan atau hendak dicapai dengan mengikuti program PPAk oleh para mahasiswa, dengan kata lain teori 
motivasi ini menjelaskan motivasi akan memberikan pengaruhnya langsung terhadap keinginan mahasiswa untuk mengambil PPAk.

2. Dalam prakteknya teori ini menganjurkan untuk menerapkan prinsip kompensasi (reward) yang dianggap berkaitan dengan motivasi ekonomi sebagai salah satu variabel dalam penelitian ini sehingga teori ini dianggap relevan dengan topik kajian ini.

\section{Pengertian Minat}

"Kemauan yang diperoleh dari dorongan kemauan, sesudah melakukan pengamatan dan memperbandingkan lalu melakukan pertimbangan dalam memenuhi kebutuhan yang sesuai dengan keinginannya" (Widyastuti dkk, 2004:327). Hampir sama dan sejalan dengan hal tersebut Tatiana dkk (2005:5) juga mendefenisikan minat sebagai berikut: minat adalah kecondongan masingmasing yang berkaitan dengan rasa baik rasa suka atu tidak terhadap sesuatu. Minat memberikan dorongan pada seseorang untuk berbuat dan memberikan perhatian terhadap apa yang diinginkan/disukainya.

Dari beberapa uraian definisi tersebut terdapat hal-hal yang harus digarisbawahi dan menjadi perhatian pada minat seperti yang dikemukakan oleh Widyastuti dkk (2004:327) adalah:
1. Anggapan pada minat sebagai penghubung/perantara berbagai faktor motivasi yang berdampak terhadap keperilakuan.

2. Minat dapat memberikan petunjuk keberanian mencoba sesorang dalam berusaha.

3. Minat memberikan petunjuk tingkat usaha/upaya individu untuk melakukan sesuatu.

\section{Pengaruh Motivasi Terhadap Minat}

Jika diamati, motivasi dan minat hampir memiliki kesamaan dalam pengertiannya yaitu keduanya merupakan motif/ keinginan/dorongan yang sama-sama muncul dari dalam diri manusia, namun terdapat pula perbedaan yang mendasar antar motivasi dengan minat, dimana motivasi lebih mengarah pada keinginan atau dorongan untuk mencapai sesuatu sedangkan minat lebih cenderung mengarah pada sikap suka atau tidak suka terhadap sesuatu.

Setiap orang pastinya memiliki suatu motivasi atau dorongan tertentu dalam melakukan sesuatu tindakan karena motivasi merupakan dasar bagi seseorang dalam melakukan sesuatu. Setelah seseorang termotivasi oleh suatu hal maka dalam dirinya akan muncul suatu minat (keinginan) untuk segera dan akan melakukan tindakan yang sejalan dengan pencapaian tujuan yang 
Vol. 2 No. 2 Bulan Oktober 2021 - Maret 2022

diinginkan agar dapat meraih apa yang pada awalnya menjadi motivator tersebut. Hal ini dapat berarti bahwa motivasi muncul lebih dulu dalam diri seseorang lalu minat mengikuti setelahnya, sehingga terwujud suatu tindakan nyata. Semakin besar daya motivasi tertanam dalam pikiran seseorang maka akan berpengaruh positif terhadap minat seseorang tersebut terhadap suatu hal.

\section{Pendidikan Profesi Akuntansi (PPAk)}

Pendidikan berbasis profesi dengan mengarahkan para akuntan agar lebih mengenal secara mendalam tentang seluk beluk profesinya dan berlangsung dalam jangka waktu sekitar dua semester. Selanjutnya gelar akuntan akan diraih sesudah menyelesaikan profesinya.

\section{Hipotesis}

Berikut beberapa hipotesis yang dapat dikemukakan yaitu:

$\mathrm{H}_{1}$ : Motivasi prestise, karir, ekonomi, dan kualitas secara serempak berpengaruh pada minat mahasiswa akuntansi untuk mengikuti PPAk.

$\mathrm{H}_{2}$ : Motivasi prestise (gengsi/status) memiliki pengaruh terhadap minat mahasiswa akuntansi

H3 : Motivasi karir berpengaruh terhadap minat mahasiswa akuntansi
H4 : Motivasi ekonomi berpengaruh terhadap minat mahasiswa akuntansi

H5 : Motivasi kualitas berpengaruh terhadap minat mahasiswa akuntansi

Dengan kerangka Berfikir sebagai berikut:

\begin{tabular}{|l|l|}
\hline 1. & Motivasi Prestise \\
2. & Motivasi Karir \\
3. & Motivasi Ekonomi \\
4. & Motivasi Kualitas
\end{tabular}$\longrightarrow \begin{gathered}\text { Minat Mahasiswa } \\
\text { Akuntansi untuk } \\
\text { Mengikuti PPAk }\end{gathered}$

\section{Metode Penelitian}

Pendekatan Asosiatif merupakan pendekatan yang digunakan dalam penelitian ini yang memiliki tujuan untuk memperoleh pengetahuan tentang keterkaitan antara dua atau lebih variabel dan memiliki bentuk keterkaitan kausal (sebab akibat) diantara dua variabelnya yaitu motivasi minat mahasiswa akuntansi.

Penelitian ini memiliki populasi semua mahasiswa dan mahasiswi jurusan akuntansi yang ada di kota Medan dan yang dijadikan sebagai sampel penelitian yaitu seluruh mahasiswa jurusan akuntansi semester 7 dan 8 di PTN di kota Medan, antara lain: USU, UNIMED. Metode pengambilan sampel dilakukan secara acak sehingga memiliki kesempatan sama dalam pemilihan responden. Penentuan besarnya sampel dilakukan dengan menggunakan rumus slovin. 
Analisis regresi linier berganda digunakan untuk menguji hipotesis. Berikut persamaan yang digunakan :

$Y=a+B_{1} X_{1}+B_{2} X_{2}+B_{3} X_{3}+B_{4} X_{4}+e$

Adapun pengujian instrumen terdiri dari uji validitas dan uji reliabilitas, uji asumsi klasik, dan uji hipotesis.

\section{Hasil Penelitian dan Pembahasan}

\section{Uji Validitas}

Uji validitas untuk setiap butir pertanyaan telah dilakukan dan diperoleh hasil $r$ hitung untuk setiap pertanyaan adalah 0,1249 atau lebih dari $\mathrm{r}$ tabel, memiliki arti pertanyaan pertanyaan untuk setiap variable dinyatakan valid. Hal tersebut dapat dilihat padat tabel 1 berikut ini :

Tabel 1 : Ringkasan Hasil Uji Validitas

\begin{tabular}{|l|c|c|c|c|}
\hline \multicolumn{1}{|c|}{ Variabel } & $\begin{array}{c}\text { Nilai r } \\
\text { hitung }\end{array}$ & $\begin{array}{c}\text { Nilai r } \\
\text { tabel }\end{array}$ & a & Keputusan \\
\hline $\begin{array}{l}\text { Motivasi } \\
\text { Prestise }\left(\mathrm{X}_{1}\right)\end{array}$ & 0,327 & 0,1249 & 0,05 & Valid \\
\hline $\begin{array}{l}\text { Motivasi } \\
\text { Karir }(\mathrm{X} 2)\end{array}$ & 0,526 & 0,1249 & 0,05 & Valid \\
\hline $\begin{array}{l}\text { Motivasi } \\
\text { Ekonomi } \\
(\mathrm{X} 3)\end{array}$ & 0,448 & 0,1249 & 0,05 & Valid \\
\hline $\begin{array}{l}\text { Motivasi } \\
\text { Kualitas }(\mathrm{X} 4\end{array}$ & 0,529 & 0,1249 & 0,05 & Valid \\
) & & & & \\
\hline Minat (Y) & 0,461 & 0,1249 & 0,05 & Valid \\
\hline
\end{tabular}

Sumber : data diolah peneliti, 2021

\section{Uji Reliabilitas}

Pengujian reliabilitas terhadap motivasi dan minat dilakukan dengan Cronbach Alpha yang menghasilkan nilai Cronbach Alpha 0,924. Artinya adalah kuesioner cukup handal yang dapat dilihat dari nilai Cronbach Alpha > 0,6 (Nunnally dalam Widyastuti 2004: 326), Berikut hasil uji reliabilitas dijelaskan pada tabel tabel 2 yaitu:

Tabel 2: Ringkasan Hasil Uji Reliabilitas

Reliability Statistics
\begin{tabular}{|c|r|}
\hline $\begin{array}{c}\text { Cronbach's } \\
\text { Alpha }\end{array}$ & N of Items \\
\hline .924 & 45 \\
\hline
\end{tabular}

Sumber : data diolah, 2021

\section{Uji Asumsi Klasik}

\section{Normalitas}

Hasil tes normalitas dengan One-Sample $K-S$ Test. Hasil Pengujian diperoleh nilai Asymp. Sig. (2 tailed) lebih besar dari $\alpha 0,05$. Hal tersebut memiliki arti bahwa penyebaran data bersifat normal yang artinya kelayakan model regresi terpenuhi karena asumsi normalitas telah terpenuhi. Hasil Uji Normalitas dapat disajikan pada tabel 3 berikut ini:

Tabel 3 Ringkasan Pengujian Normalitas

\begin{tabular}{|l|c|c|c|}
\hline \multicolumn{1}{|c|}{ Variabel } & $\begin{array}{c}\text { Asymp Sig (2- } \\
\text { tailed) }\end{array}$ & a & Keputusan \\
\hline Motivasi Prestise $\left(\mathrm{X}_{1}\right)$ & 0,241 & 0,05 & Normal \\
\hline Motivasi Karir $(\mathrm{X} 2)$ & 0,062 & 0,05 & Normal \\
\hline Motivasi Ekonomi (X3 & 0,426 & 0,05 & Normal \\
\hline & & 0,05 & Normal \\
\hline Motivasi Kualitas (X4) & 0,085 & 0,05 & Normal \\
\hline Minat $(\mathrm{Y})$ & 0,100 & 0, & \\
\hline
\end{tabular}

Sumber : data diolah, 2021 
Heteroskedastisitas

Untuk mengetahui terjadi heteroskedastisitas atau tidaknya dilakukan Uji Glejser yang diperoleh hasil yang dapat dilihat pada tabel 4. Dimana probabilitas signifikansinya lebih besar dari $\alpha-=0,05$, sehingga dapat diartikan tidak terdapat gejala heteroskedastisitas pada model regresi, yang berarti model regresi memiliki kelayakan untuk digunakan/dipakai. Output Uji heteroskedastisitas terdapat pada tabel 4 berikut ini:

\begin{tabular}{|c|c|c|c|}
\hline Variabel & AbsUt & a & Status \\
\hline $\begin{array}{ll}\text { Motivasi } & \text { Prestise } \\
\left(\mathrm{X}_{1}\right) & \\
\end{array}$ & 0,063 & 0,05 & Tidak tejadi heteroskedastisitas \\
\hline Motivasi Karir (X2) & 0,479 & 0,05 & Tidak terjadi heteroskedastisitas \\
\hline $\begin{array}{l}\text { Motivasi Ekonomi } \\
\text { (X3) }\end{array}$ & 0,085 & 0,05 & Tidak terjadi heteroskedastisitas \\
\hline $\begin{array}{ll}\text { Motivasi } & \text { Kualitas } \\
(\mathrm{X} 4) & \end{array}$ & 0,327 & 0,05 & Tidak terjadi heteroskedastisitas \\
\hline
\end{tabular}

Sumber : data diolah, 2021

\section{Multikolinieritas}

Multikolinieritas ditunjukkan jika terdapat hubungan yang linier antara variable bebas dalam model. Dari hasil pengujian diperoleh informasi nilai VIF semua variable bebas lebih kecil dari 10 dan nilai toleransi lebih besar dari 0,1. Artinya bahwa tidak ada hubungan antara variable bebas (tidak terdapat/terjadi multikoliniritas) pada model. Untuk lebih jelasnya output multikolinieritas terdapat dalam tabel 5 yaitu :
Tabel 5: Ringkasan Pengujian Multikolinieritas

\begin{tabular}{|c|c|c|c|}
\hline Variabel & Tolerance & VIF & Status \\
\hline Motivasi Prestise $\left(X_{1}\right)$ & 0,773 & 1,293 & Tidak terjadi multikolinienitas \\
\hline Motivasi Karir $(\mathrm{X} 2)$ & 0,395 & 2,531 & Tidak terjadi multikolinienitas \\
\hline Motivasi Ekonomi $(\mathrm{X} 3)$ & 0,863 & 1,159 & Tidak terjadi multikolinienitas \\
\hline Motivasi Kualitas $(\mathrm{X} 4)$ & 0,478 & 2,091 & Tidak terjadi multikolinienitas \\
\hline
\end{tabular}

Sumber : data diolah, 2021

\section{Uji Hipotesis}

Pengujian hipotesis pertama sampai dengan hipotesis ke lima dilakukan dengan persamaan adalah:

$Y=\alpha+\beta_{1} X_{1}+\beta_{2} X_{2}+\beta_{3} X_{3}+\beta_{4} X_{4}+e$; atau $Y=3,314-0,089 X_{1}+0,050 X_{2}+0,181 X_{3}+$

\section{$0,266 \mathrm{X}_{4}+\mathrm{e}$}

Untuk memutuskan adanya pengaruh secara serempak atau bersama-sama (over all test ratio) antara variabel bebas $(\mathrm{X})$ terhadap variabel terikat (Y) alat uji yang dipergunakan adalah dilihat dari nilai $\mathrm{F}$ hitung dengan tingkat signifikansi $\alpha=0,05$ adalah 21,655 sedangkan $\mathrm{F}$ tabel adalah 2,445. Jadi $F$ hitung $>F$ tabel yang berarti bahwa $\mathrm{H}_{1}$ diakui/diterima, dengan demikian secara serempak (simultan) motivasi prestise, karir, ekonomi, dan motivasi kualitas berpengaruh terhadap minat mahasiswa akuntansi untuk mengambil PPAk.

Melihat kondisi di atas, dapat diperjelas bahwa koefisien variabel motivasi prestise adalah $\mathrm{B} 1=-0,089$ dan itu berarti setiap kenaikan variabel motivasi prestise sebesar 1 


\section{Vol. 2 No. 2 Bulan Oktober 2021 - Maret 2022}

maka minat mahasiswa akuntansi untuk mengambil PPAk akan berkurang sebesar 8,9 $\%$ dengan asumsi variabel lainnya dianggap tetap. Variabel motivasi prestise secara parsial mempunyai nilai sig. $\mathrm{t}=0,945$ atau $\mathrm{t}$ hitung < t tabel $(1,282)$. Hal Ini menunjukkan bahwa secara parsial variabel motivasi prestise $\left(\mathrm{X}_{1}\right)$ tidak memiliki pengaruh besar terhadap minat mahasiswa akuntansi (Y) dengan tingkat signifikansi $\alpha=0,05$ sehingga $\mathrm{H}_{2}$ ditolak. Hal ini bisa jadi karena para mahasiswa beranggapan bahwa mengambil PPAk dan memperoleh gelar Ak tidak akan berpengaruh banyan terhadap penngkatan prestise (status/gengsi) mereka di tengahtengah masyarakat dan komunitas merekan karena gelar tersebut masih kurang menjanjikan untuk masa depan jika dibandingkan kalua mereka meraih gelar S2 . Variabel motivasi karir $\left(\mathrm{X}_{2}\right)$ menghasilkan koefisien $\beta 2=0,50$ yang berarti setiap kenaikan variabel motivasi karir sebesar 1, maka minat mahasiswa akuntansi untuk mengambil PPAk akan meningkat sebesar 50 $\%$ dengan variabel lainnya dianggap tetap sebagai asumsi. Variabel motivasi karir secara parsial/sebagian memiliki sig. $\mathrm{t}=5$, 530 atau $\mathrm{t}$ hitung $>\mathrm{t}$ tabel $(1,282)$. Hal Ini berarti secara parsial variabel motivasi karir $\left(\mathrm{X}_{2}\right)$ memiliki pengaruh secara signifikan terhadap minat mahasiswa akuntansi (Y) dengan tingkat signifikansi $\alpha=0,05$ yang berarti diterimanya hipotesis $\mathrm{H}_{3}$. Ini mungkin karena siswa merasa bahwa pekerjaan yang lebih tinggi adalah prioritas yang lebih tinggi daripada masalah kualitas dan keuangan atau imbalan uang untuk mendorong siswa mengambil PPAk untuk mencapai situasi yang lebih tinggi dalam pekerjaan mereka.

Variabel $\mathrm{X}_{3} \quad$ (motivasi ekonomi) memberikan hasil nilai $\mathrm{B}_{3}=0,181$ yang dimaksudkan bahwa untuk setiap peningkatan variabel $\mathrm{X}_{3}$ (motivasi ekonomi) senilai 1, maka minat siswa akuntansi untuk mengambil PPAk akan meningkat senilai $18,1 \%$ dimana variabel yang lainnya dianggap tetap. Variabel $\mathrm{X}_{3}$ (motivasi ekonomi) secara parsial/sebagian memiliki nilai sig. $\mathrm{t}=4,972$ atau $\mathrm{t}$ hitung $>\mathrm{t}$ tabel $(1,282)$. Hal Ini memiliki arti bahwa secara parsial variabel motivasi ekonomi $\left(\mathrm{X}_{3}\right)$ memiliki pengaruh secara signifikan terhadap minat mahasiswa akuntansi (Y) dengan tingkat signifikansi $\alpha=0,05$ yang berarti diterimanya hipótesis empat/ $\mathrm{H}_{4}$. Perihal tersebut bisa saja dikarenakan mahasiswa berpendapat dengan mengikuti PPAk mereka dapat memperoleh pekerjaan di kantor akuntan publik maupun perusahaan serta tawaran pekerjaan dari klien yang lebih menjanjikan dan lebih baik, dengan demikian 
secara langsung mereka juga dapat menerima gaji yang tinggi (penghargaan finansial)

Sementara itu variabel motivasi kualitas $\left(\mathrm{X}_{4}\right)$ menghasilkan koefisien $\mathrm{B}_{4}=0,266$ memiliki arti setiap peningkatan variabel $\mathrm{X}_{4}$ (motivasi kualitas) senilai 1, minat mahasiswa akuntansi dalam mengambil PPAk meningkat senilai $26,6 \%$ dimana variabel lainnya dianggap tetap.Variabel motivasi kualitas secara parsial/sebahagian memiliki sig. $\mathrm{t}=7,110$ atau $\mathrm{t}$ hitung $>\mathrm{t}$ tabel (1,282). Hal tersebut menunjukkan bahwa secara parsial variabel motivasi kualitas $\left(\mathrm{X}_{2}\right)$ memiliki pengaruh secara signifikan terhadap minat mahasiswa akuntansi (Y) dengan tingkat signifikansi $\alpha=0,05$ yang berarti diterimanya hipótesis lima/ $\mathrm{H}_{5}$. Perihal tersebut bisa saja dikarenakan mahasiswa memiliki anggapan dengan mengikuti PPAk mereka dapat memperoleh ilmu pengetahuan, keterampilan profesi, isu-isu terkini di bidang akuntansi, dan gambaran tentang dunia akuntansi secara menyeluruh sehingga dengan demikian mereka dapat meningkatkan kualitas dan mutu pelayanan terhadap klien sebagai seorang akuntan yang profesional.

$R$ square (koefisien determinasi) yang didapat adalah senilai 0,464 , memiliki arti $46,4 \%$ terjadinya perubahan minat mahasiswa akuntansi untuk mengambil
PPAk dipengaruhi oleh variabel motivasi prestise, motivasi karir, motivasi ekonomi, dan motivasi kualitas. Sementara itu sisanya sebesar 53,6 \% lainnya dipengaruhi oleh faktor selain faktor yang dirujuk di atas yang tidak terdapat dalam ulasan ini. Untuk lebih jelasnya ringkasan hasil pengujian hipotesis 1 sampai dengan 5 disajikan dalam tabel 6 berikut ini:

Tabel 6: Ringkasan hasil pengujian hipotesis 1 sampai dengan 5

\begin{tabular}{|c|c|c|c|c|c|}
\hline Model Variabel & B & $\begin{array}{c}\text { Standar } \\
\text { Error }\end{array}$ & $\begin{array}{c}\text { t hitung } \\
\text { simultan }\end{array}$ & $\begin{array}{c}R \\
\text { square }\end{array}$ & $\begin{array}{c}\text { thitung } \\
\text { parsial }\end{array}$ \\
\hline Konstanta & 3,314 & 2,237 & 1,481 & 0,464 & \\
\hline $\mathrm{X} 1$ & $-0,089$ & 0,047 & $-1,881$ & 0,464 & 0,945 \\
\hline $\mathrm{X} 2$ & 0,050 & 0,071 & 0,711 & 0,464 & 5,530 \\
\hline $\mathrm{X} 3$ & 0,181 & 0,038 & 4,722 & 0,464 & 4,972 \\
\hline $\mathrm{X} 4$ & 0,266 & 0,059 & 4,533 & 0,464 & 7,110 \\
\hline
\end{tabular}

Sumber : data diolah, 2021

\section{Kesimpulan dan Saran}

\subsection{Kesimpulan}

Merujuk pada hasil output, maka dapat disimpulkan bahwa dari hasil pengujian hipotesis pertama sampai dengan ke lima dengan pendekatan/model regresi berganda diperoleh hasil pengujian serentak (simultan) motivasi prestise, motivasi karir, motivasi ekonomi, dan motivasi kualitas berpengaruh terhadap minat/keinginan mahasiswa akuntansi untuk mengikuti PPAk. Namun secara parsial/sebagian motivasi prestise tidak berpengaruh signifikan terhadap munculnya minat mahasiswa akuntansi untuk mengikuti PPAk. Variabel 
motivasi karir, motivasi ekonomi, dan motivasi kualitas berpengaruh terhadap minat.

\subsection{Saran}

1. Kajian berikutnya hendaknya bias mengembangkan objek yang diteliti menjadi lebih luas, tidak hanya melihat motivasi apa yang berpengaruh terhadao minat/keinginan mahasiswa akuntansi dalam proses pembelajan di PPAk namun juga meneliti berbagai faktor apa yang menyebabkan minat tersebut muncul dan mengemukakan faktor dan alasan apa yang menyebabkan mahasiswa tidak begitu antusias mengikuti PPAk.

2. Penelitian selanjutnya bisa memperluas dan menambah jumlah sampel dari masing-masing kriteria sesuai proporsi masing-masing kriteria agar penelitian lebih objektif.

3. Menambah bahasan yang berkaitan dengan motivasi serta pengaruh motivasi terhadap minat/keinginan agar lebih terlihat jelas hubungan di antara keduanya.

\section{DAFTAR PUSTAKA}

Arifianto, F., \& Sukanti. (2014). Pengaruh motivasi diri dan persepsi mengenai profesi akuntan publik terhadap minat menjadi akuntan publik pada mahasiswa Prodi Akuntansi Fakultas
Ekonomi Universitas Negeri Yogyakarta. Jurnal Nominal, 3(2), 150161.

Gibson, James L; Ivancevich, John M; Donnelly Jr, James $\mathrm{H}$ and Konopaske, Robert. 2003. Organizations : Behavior, Structure, Processes. Eleventh Edition. Amerika: The MvGraw-Hill Companies, Inc.

Jackling, B., de Lange, P., Phillips, J., \& James, S. (2012).Attitudes towards accounting: Differences between Australian and international students. Accounting Research Journal, 25(2), 113-130.

Kusumastuti, R., \& Waluyo, I. (2013). Pengaruh motivasi dan pengetahuan UU Nomor 5 Tahun 2011 tentang akuntan publik terhadap minat mahasiswa akuntansi mengikuti pendidikan profesi akuntansi (PPAk). Nominal, 2(2), 1-30.

Maksum, Azhar. 2005. Persepsi Alumni dan Mahasiswa Jurusan Akuntansi Terhadap Pendidikan Profesi Akuntansi (PPAk). Solo: Simposium Nasional Akuntansi II.

Munandar, Ashar Sunyoto. 2001. Psikologi Industri dan Organisasi. Jakarta: UIPress.

Peraturan Menteri Pendidikan dan Kebudayaan Republik Indonesia Nomor 153 Tahun 2014 tentang Penyelenggaraan Pendidikan ProgramProfesi Akuntan.

Robbins, Stephen P. 2002. Prinsip-Prinsip Perilaku Organisasi. Edisi ke lima. Jakarta: Erlangga. 
Sugiyono. 2005. Metode Penelitian Bisnis. Cetaakan Kedelapan. Bandung: ALFABETA.

Tatiana, A. Endang dan Soetjipto, Budi. W. 2005. Model Prestasi Akademik Mahasiswa: Potensi Akademik dan Gaya Belajar. Jakarta: Manajemen Usahawan Indonesia, No. 04/TH.XXXIV April 2005.

Veithzal, Rivai. 2004. Manajemen Sumber Daya Manusia Untuk Perusahaan: dari Teori ke Praktik. Jakarta: PT. Raja Grafindo Persada.

Widyastuti, Sri Wahyuni, Suryaningsum, Sri, dan Juliana, Kiki. 2004. Pengaruh Motivasi Terhadap Minat Mahasiswa Akuntansi Untuk Mengikuti Pendidikan Profesi Akuntansi (PPAk). Denpasar Bali: Simposium Nasional Akuntansi VII. 